\title{
Research on the Influence Strategy of WeChat Official Accounts of Colleges and Universities
}

\author{
Huo Bintao \\ Beijing International Studies University \\ Email: huobintao@bisu.edu.cn
}

\begin{abstract}
Currently, WeChat official accounts of colleges and universities have became prevalent windows for dissemination of information, propaganda of news and construction of brand. These official accounts serve as one of the platform that have attracted the most attentions among colleges and universities at present. The majority of audience of colleges' and universities' official accounts on WeChat are students, alumni and teachers. Based on the experience of managing and operating Beijing International Studies University (BISU)'s WeChat official account, the author makes an analysis on WeChat push with a wide readership, probing into the operation strategy of WeChat official account of colleges and universities for the purpose of providing enlightenment for colleges and universities to disseminate the information.
\end{abstract}

Keywords - Colleges and universities; WeChat official accounts, Operation; Strategy

\section{INTRODUCTION}

BISU's WeChat Official Account was officially started on November 17, 2013, with an average annual posts of more than 300. As of September 1, 2017, it had more than 39,000 followers. With its increasing publicity power within and outside the universities, it has been successfully listed in the top 100 Chinese universities' new media of 2016, ranking number one among all foreign language schools, having ever ranked sixth in National Colleges and Universities' WeChat Official Account list released by China Youth News, having ever ranked second in Beijing district's new media list. Since its register, BISU's WeChat Official Account has taken a significantly active role in advertising BISU's central work, promoting the common theme, guiding the network public opinion and advancing the healthy development of campus network culture.

\section{ANALYZING THE INFLUENCE OF WECHAT PUBLIC ACCOUNT FROM THE PERSPECTIVE OF SAMPLE DATA}

The sample data is selected from three years of WeChat post statistics from January 1, 2014 to December 31, 2016, within which in total 986 articles have been published with average posts of 28 per month. The number of articles clicked more than 5000 times was up to 230 , accounting for $23.3 \%$ of whole publishing volume; the number of articles clicked more than 10000 reached 77, occupying 7.8\% respectively. Among articles clicked more than 10000 , the sorts of contents with high pushing rate are character communication (6 articles), poem ( 5 articles), topic ( 9 articles), life (17 articles), messages (20 articles) and subject (20articles).

\section{The Strategies of Publishing High Clicked Contents}

Colleges and universities' WeChat Official Account acts as an important instrument and platform for campus to disseminate the information [1]. The spread power, ultimately based on the content, is a significant criteria in judging and evaluating whether it is effective. WeChat Official Account, by virtue of its "official" identity, can cover exclusively and publish at the first place etc in term of content. But only when the contents pushed have been viewed or forwarded by followers, it might be considered to have completed its missions of information dissemination and value delivery.

By means of in-depth interviewing with audience teachers and students and counting the readership of WeChat pushed content, I found that BISU's WeChat Official Account contents with quite a wide leadership of more than 10000 have the following characteristics:

\section{A. The Sense of Identity and Belonging for the University}

More than $60 \%$ of students following the WeChat Public Account deprive from the sense of identity and belonging for the university. In the process of collecting and analyzing the statistics, we see that the sense of identity and belonging are important approaches which enhance the influence of WeChat Public Account in colleges and universities and enhance audience loyalty. We select three pushed contents with readership of more than 10000 : 
"[The Front Page of Guangming Daily] BISU: A "Small and Beautiful" University"; "BISU Girls-BISU's First MV Exclusive for Girls"; "Fifty Years of Trials, All Making For Spectrum-BISU's Fifty Anniversary Documentary". "BISU Girls sing for all girls' heart in BISU", letting them strongly resonate with each other. The report of "Front Page of Guangming Daily" which has been taken as a pride by all BISU's teachers and students has significantly increased
BISU's popularity and reputation. "BISU's Fifty Anniversary Documentary" fully sports achievement of university's development, arousing all members' sense of identity and belonging about constructing and loving BISU.

TABLE I. THE SENSE OF IDENTITY AND BELONGING FOR THE UNIVERSITY

\begin{tabular}{|c|c|c|c|c|}
\hline Title & Releasing time & $\begin{array}{c}\text { The Amount of } \\
\text { Audience }\end{array}$ & $\begin{array}{c}\text { The } \\
\text { Amount of } \\
\text { Readership }\end{array}$ & $\begin{array}{c}\text { The Amount of } \\
\text { Sharing }\end{array}$ \\
\hline $\begin{array}{c}\text { BISU Girls-BISU's First MV Exclusive } \\
\text { for Girls; Fifty Years of Trials }\end{array}$ & $2017-6-24$ & 37330 & 26603 & 1970 \\
\hline $\begin{array}{c}\text { [The Front Page of Guangming Daily] } \\
\text { BISU: A "Small and Beautiful" } \\
\text { University }\end{array}$ & $2014-10-23$ & 8494 & 25746 & 1003 \\
\hline $\begin{array}{c}\text { Fifty Years of Trials, All Making For } \\
\text { Spectrum-BISU's Fifty Anniversary } \\
\text { Documentary }\end{array}$ & $2014-10-23$ & 8494 & 16521 & 1261 \\
\hline
\end{tabular}

\section{B. The Dissemination with "Temperature"}

"Temperature" is a significant factor to affecting the dissemination of information [3]. With the "temperature", it inevitably narrows the distance between the university and teachers as well as students. The dissemination of information is no longer cold, but warm and heart-touching. "The 2015 Official Enrollment Propaganda Film of BISU" focuses on affection of alumni, promoting alma mater from the perspective of alumni representatives which enjoys high identity and authority. In addition, the following warm push contents bathe the students like warm breeze, boasting obvious dissemination results: "In the BISU, Expecting to Meet the Best You in the Most Beautiful Time ", "Advocation of Donating for Liu Guochao in the Japanese Language School of BISU", "I Love BISU with More Than 52 Reasons. No, I Love BISU, Do not Need Reason".

TABLE II. THE DISSEMINATION WITH "TEMPERATURE" EFFECTIVENESS, EMOTIONAL

\begin{tabular}{|c|c|c|c|c|}
\hline Title & Releasing time & $\begin{array}{c}\text { The Amount of } \\
\text { Audience }\end{array}$ & $\begin{array}{c}\text { The Amount of } \\
\text { Readership }\end{array}$ & $\begin{array}{c}\text { The Amount of } \\
\text { Sharing }\end{array}$ \\
\hline $\begin{array}{c}\text { [Never copy] The 2015 Official Enrollment } \\
\text { Propaganda Film of BISU }\end{array}$ & $2015-6-10$ & 15873 & 63163 & 1955 \\
\hline $\begin{array}{c}\text { In the BISU, Expecting to Meet the Best } \\
\text { You in the Most Beautiful Time }\end{array}$ & $2016-6-8$ & 27073 & 15033 & 865 \\
\hline $\begin{array}{c}\text { Advocation of donating for Liu Guochao in } \\
\text { the Japanese Language School of BISU }\end{array}$ & $2015-5-13$ & 14390 & 18608 & 2595 \\
\hline $\begin{array}{c}\text { I Love BISU with more than 52 reasons. } \\
\text { No, I Love BISU, Do not Need Reason }\end{array}$ & $2016-10-24$ & 31001 & 32905 & 2595 \\
\hline
\end{tabular}

\section{Role Models, Transferring Positive Energy}

The power of role models is ever self-evident due to searching for and reporting the role models of teachers, students and alumni, enhancing education of the socialist core values and transferring positive energy [2]. The current foreign minister Wang Yi, the alumnus of BISU, whose activities have profound impacts on teachers and students in BISU, attracted countless fans, so "I Heard That You Have Recently Been the
Fan of My Wang Yi Alumni?" acquired quite a wide readership, resulting in huge education effects on students' positive energy. "High-end Simultaneous Interpreters Among Eight Languages, BISU's Teachers" started from the language teachers who were taken as proud by students in BISU, so that students got to know the strength of the teachers around them, thus completing their studies with excellent grades. "Be Serious: I am actually not a Model, But a Professor" 
distinguishes BISU with the characteristics of "international" by composing the character of foreign teacher.

TABLE III. Role Models, Transferring Positive IMAGE AND VALUE

\begin{tabular}{|c|c|c|c|c|}
\hline Title & Releasing time & $\begin{array}{c}\text { The Amount of } \\
\text { Audience }\end{array}$ & $\begin{array}{c}\text { The Amount of } \\
\text { Readership }\end{array}$ & $\begin{array}{c}\text { The Amount } \\
\text { of Sharing }\end{array}$ \\
\hline $\begin{array}{c}\text { High-end simultaneous interpreters } \\
\text { among eight languages, BISU's } \\
\text { teachers }\end{array}$ & $2014-9-23$ & 7594 & 18253 & 1263 \\
\hline $\begin{array}{c}\text { I Heard That You Have Recently Been } \\
\text { the Fan of My Wang Yi Alumni? }\end{array}$ & $2016-7-17$ & 29329 & 29715 & 1334 \\
\hline $\begin{array}{c}\text { Be Serious: I am Actually not a Model, } \\
\text { But a Professor" }\end{array}$ & $2016-4-5$ & 25154 & 15209 & 1036 \\
\hline
\end{tabular}

D. Concerning About the Interests of Teachers and Students

The pushes concerning about the interests of teachers and students inevitably receive a good communication effects. With quite a few girls in BISU, the readership of the pushes "Girls in
BISU Welcome the Age of Bathhouse 2.0" and "Girls in BISU can not be bullied" reached more than 25000. WeChat Public Account has gained great popularity among masses of students because it thinks what students think and push articles from fundamental interests of students.

TABLE IV. CONCERNING ABOUT THE INTERESTS OF TEACHERS AND STUDENTS

\begin{tabular}{|c|c|c|c|c|}
\hline Title & Releasing time & $\begin{array}{c}\text { The Amount of } \\
\text { Audience }\end{array}$ & $\begin{array}{c}\text { The Amount of } \\
\text { Readership }\end{array}$ & $\begin{array}{c}\text { The Amount of } \\
\text { Sharing }\end{array}$ \\
\hline $\begin{array}{c}\text { [Official Release] 2016 Autumn } \\
\text { Term School Calendar+ New Daily } \\
\text { Schedule }\end{array}$ & $2016-8-5$ & 29735 & 15836 & 546 \\
\hline $\begin{array}{c}\text { Girls in BISU Welcome the Age of } \\
\text { Bathhouse 2.0 }\end{array}$ & $2015-3-11$ & 10978 & 27242 & 590 \\
\hline Girls in BISU can not be bullied & $2015-5-26$ & 15078 & 25370 & 472 \\
\hline
\end{tabular}

IV. THE StRATEGY OF WeChAt RELEASING FoRM ON GAINING A WIDE READERSHIP

The selection of transmission of symbols is of great importance in the strategy part of WeChat releasing form. Of selected pushing data with the readership of more than 10000 , $100 \%$ spread through text and pictures, 35\% spread through the form of audio and video, another $15 \%$ through the interaction between WeChat Public Account and teachers as well as students, $4 \%$ through the video $\backslash$ text live form .

WeChat push "[Never copy] The 2015 Official Enrollment Propaganda Film of BISU" is a typically push using text and pictures. So it is self-evident how important it is for the effect of push in WeChat Public Account to make high-quality and thoughtful special propaganda video. 


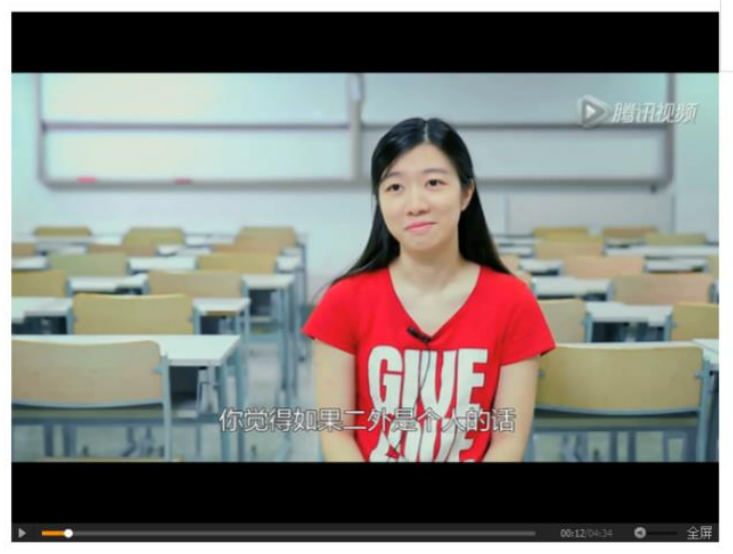

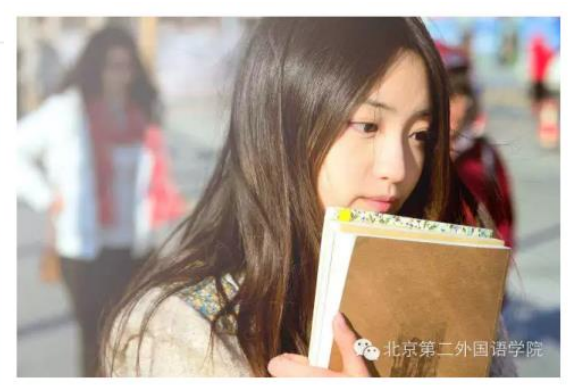

$$
\text { 然而，然而 }
$$

这样的话, 就再也没有机会在七点四十起我

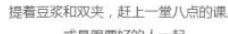
或是㩆要好的人一起

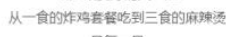

Fig. 1 WeChat push "[NeVer Copy] The 2015 Official Enrollment Propaganda Film of BisU”

WeChat push "You are Reading That Correctly, BISU is Really Selecting Campus Flower This Time" is the activity to choose campus flower by voting among teachers and students in university. High involvement among teachers and students

\section{你没看错，这次二外是真的要选校花了!}

(原创) 2017-04-17 翔宇东方新闻社 北京第二外国语学院

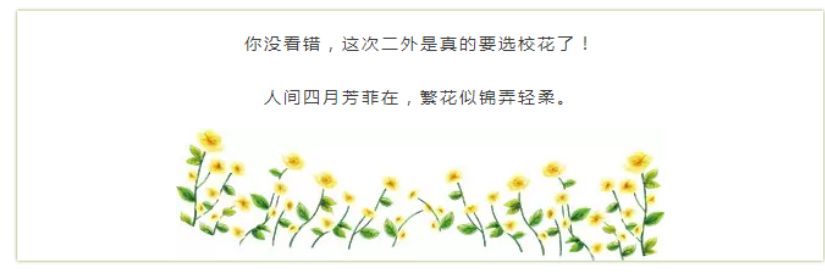

热情似火还是温婉如水? 高贵冷绝还是兰质茦心? 亚丽端庄还是古灵精怪? 你们眼中的二外校花需要get唧种 气质呢? 快快加入进来, 小薇已经为你预选了1 0 种花，如果你认为有其它的花更符合二外的气质，也可以在 评论区留言并写出推荐的理由。动动手指，二外“校花”由你定哦！(咳咳，稍作提醒：此校花非彼校花 哦，这是真花 )

\section{投票时间 : 即日起至 4 月 24 日}

投票标准 : 所选 “校花” 应体现出二外的气质与精神。

投票说明 : 本次微信投票结果为重要参考。评选活动将综合微信、网站等线上投票结果 (占比 $30 \%$ ) 以及 线下投票结果（占比 $30 \%$ ），并听取专家评审团意见（占比 $40 \%$ ），最终确定二外“校花”，第一时间公 布。 fully shows the excellent school spirit of teachers and students in BISU to construct and love the campus and the high identity of the university.
你心中的二外校花是什么? (单选)
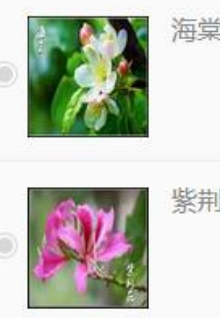

紫荆花
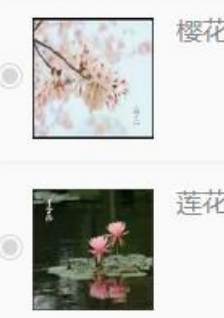

Fig. 2 WeChat Push "You are Reading That CoRrectly, BISU is ReAlly Selecting CAMPUS Flower This Time"

WeChat push"[Global live] 2015bisuers Celebrate New Year's Eve Countdown Party Together". It used the form of live video to display a different experience of spending New
Year's Eve for teachers and students, letting individuals who can not go to the scene share happy ceremony. 


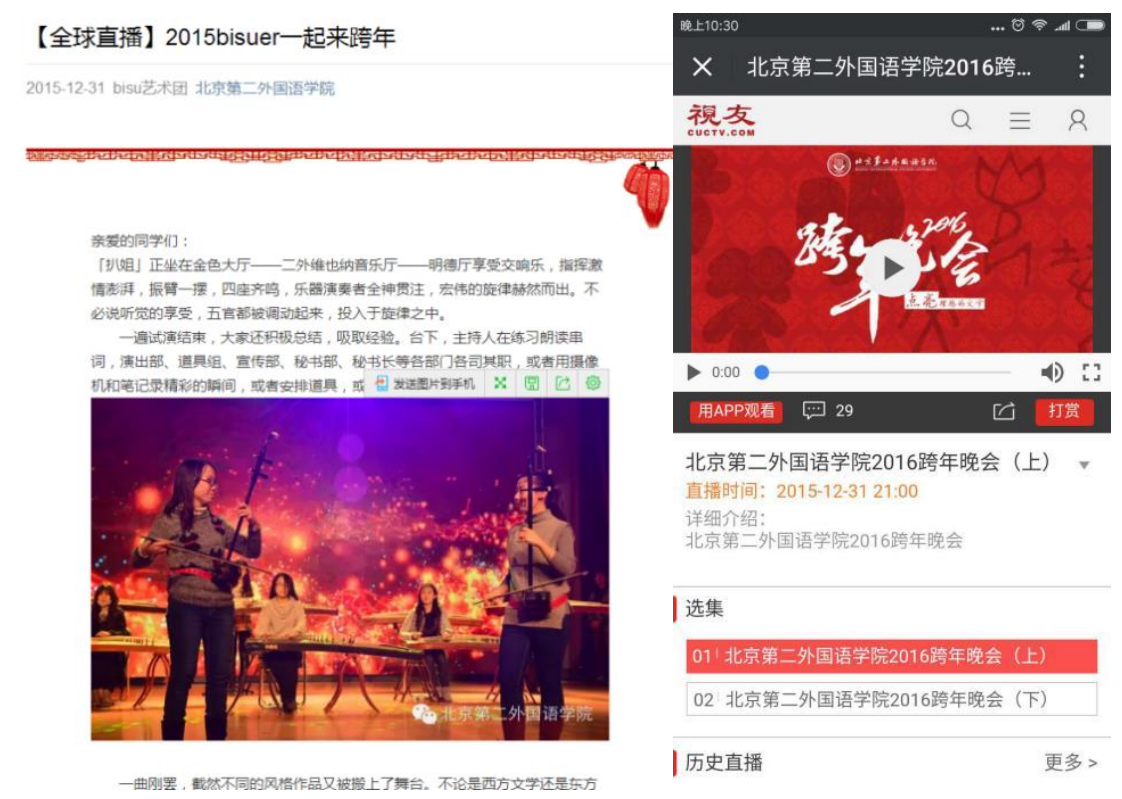

Fig. 3 WeChat push"[Global live] 2015 Bisuers Celebrate New Year's Eve Countdown Party Together"

\section{CONCLUSION}

The official Wechat has been an indispensable channel for universities to send messages and express opinions [4]. The excellent content production of university's official Wechat must be demand-oriented and user-centered (both teachers and students should be considered). It is supposed to look for clues and dig out typical examples. Meanwhile, it should innovate form and strategy of information release and make full use of new media. With the improvement of the media technology, developing new media, such as Wechat, is the irresistible trendency. University's official Wechat needs to be utilized properly to promote college propaganda [5]. It can not only boost university's reputation and enhance cultural soft power, but also build image and serve public opinion management.

\section{REFERENCES}

[1] Huang Chuyun, Peng Qilin. A Study of Motivation and Communication Effect of University's WeChat Public Platform-A Case study of Central South University WeChat platform [J]. Southeast Communication, 2017(8):122-124.

[2] Xiang Ling, Cao Dan. A Study on the Operation Strategy of University's Wechat Subscription-Take Sichuan University's Wechat as an Example [J]. Radio\&TV Journal,2017(8): 171-172.

[3] Jiang Lihong, A Study on the Transmission and Influence of University's Wechat Public Platform-Take Guangxi University as an Example [J]. Electronic Commerce, 2015(12):70-73.

[4] Zhao Ni, Wang Kengqi. A Study on the Content of University's Wechat Subscription under the Internet Thinking Parttern [J]. Journal of Guang Dong Communication Polytechnic, 2016 (1):49-52.

[5] Cao Shisheng. A Study on the Operation Strategy of University's Offical Wechat Subscription-Take Central China Normal University's Official Wechat Subscription as an Example [J]. New Media Research, 2016(5):55-5. 